\title{
EXPECTING A BOOMTOWN? EXPLORING POTENTIAL HOUSING - RELATED IMPACTS OF LARGE SCALE RESOURCE DEVELOPMENTS IN DARWIN
}

\author{
Gretchen Ennis, * Mary Finlayson, Glen Speering
}

Research Centre for Health and Wellbeing, Charles Darwin University, Australia

\begin{abstract}
Darwin is a city in the Northern Territory of Australia expecting a 'boomtown' scenario due to significant natural resource developments in the Greater Darwin area. The experience of 'booming' has a range of impacts upon communities. Housing is a key area of impact, particularly for the most vulnerable members of a population, who may not reap the benefits of the 'boom'. In Darwin, new resource developments will begin in the context of record high house prices, high rents and high homelessness rates. This literature review explores what is known about the housing-related impacts of boomtowns and considers the likely housing-related impacts of a boomtown scenario in Darwin. While the city's diverse economy and population size may provide some insulation from severe boomtown impacts, housing availability and affordability is likely to be negatively impacted. The implications of this for the most vulnerable members of the greater Darwin population require careful consideration.
\end{abstract}

Key words: Housing, Boomtown, Darwin, Resource development.

Article Info: Manuscript Received: December 4, 2012; Revised: April 12, 2013; Accepted: April 25, 2013; Online: May $25,2013$.

\section{Introduction}

Darwin is a small city located in the Northern Territory of Australia (see figure 1) which is in the early stages of a population and economic 'boom' due in large part to new major resource developments in the Greater Darwin area. While the experience of rapid growth can have both positive and negative social impacts, the impacts upon housing affordability and availability are generally negative, particularly for the vulnerable members of a population. In Darwin, new resource developments begin in the context of record high house prices, high rents and high homelessness rates. The expected increases in worker population (fly-in, fly-out workers and more permanent workers who may move to Darwin with their families) will place additional strain upon the existing housing supply.

The aim of this literature review is to determine what is known about housing-related impacts of boomtown scenarios, and to relate this literature to the current situation in Darwin. In the first instance

\footnotetext{
* Corresponding author:

Address: Research Centre for Health \& Wellbeing, Charles Darwin

University, Darwin, Northern Territory 0909, Australia

Telephone: +61 (o8) 89467655

Email: gretchen.ennis@cdu.edu.au
}

we outline the concept of 'boomtowns' and explore the housing-related impacts of booming in international and Australian contexts. Drawing from a range of material, the already stressed housing market in Darwin is discussed and the likely housingrelated impacts of new major resource developments are overviewed. The anticipated effects of these changes require careful consideration, particularly for the most vulnerable residents in Darwin.

\section{Conducting the literature review}

This literature review has two main aims. The first aim is to gain an understanding of the housingrelated impacts of boomtowns, particularly in terms of the vulnerable members of boomtowns. The second aim is to explore these impacts in relation to the Greater Darwin area as it enters the early stages of booming.

To understand what is already known about housing-related impacts of booming, literature was located via a range of databases. Academic Search Premier, E-Journals, Humanities International Complete and SocINDEX data bases were used, with date limits 1970 to 2012. The search term 'boomtown' returned 87 results. This was further reduced to 58 
articles after scanning all returns and eliminating articles that did not concern resource development related booming, or were focused on environmental and conservation issues. The reference lists in these articles were consulted for further sources.

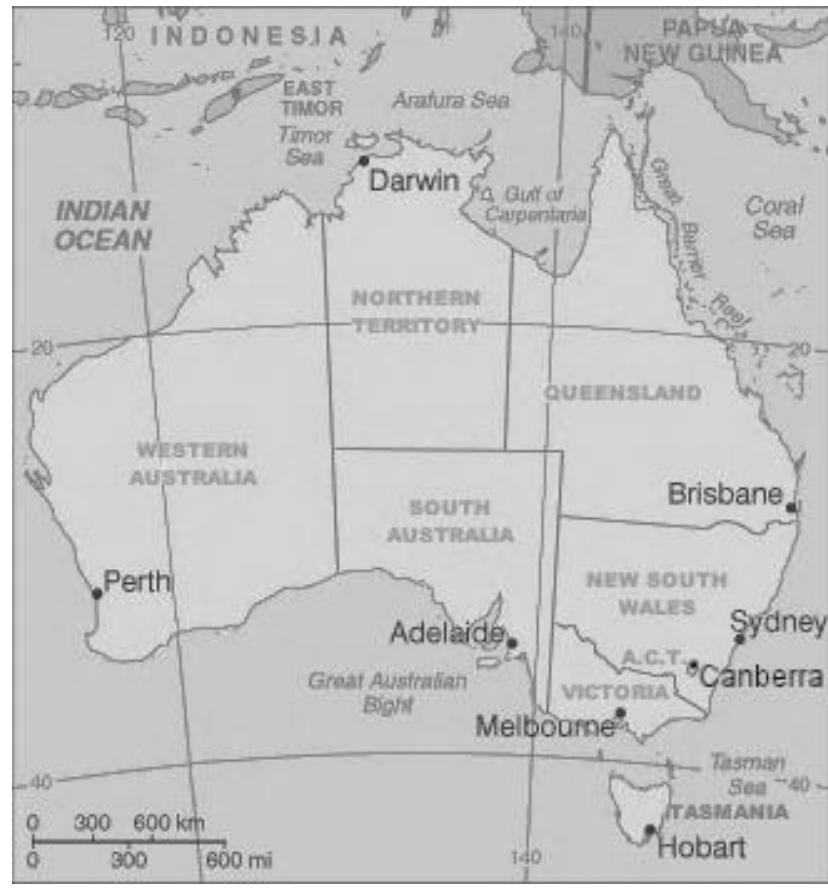

Figure 1. Map of Australia with Darwin located in the far North

To understanding the current housing context in Darwin, further literature was gathered Firstly, using the same data bases and time fames as noted above, the search terms 'Darwin' 'Australia' 'Northern Territory' yielded 345 results. A further search term 'social' was added, reducing the results to 76 . Only one paper concerning housing or social impacts of resource development was located, reflecting a lack of published material about housing in Darwin.

The search for Darwin related material was widened to include a range of online sources and this resulted in a range of reports from government and non-government organisations, peak housing, community service and real estate bodies, resource companies as well as news media reports. This information combined with population data from the Australian Bureau of Statistics has been used to describe and explore the Darwin context.

\section{Boomtowns}

A 'boomtown' is a place experiencing sudden and rapid growth in terms of population and economy. The cause of growth is generally related to the exploitation of natural resources in large scale corporate projects, typically involving the oil and gas industries. Rapid and large scale growth has major social and economic impacts on communities. Gilmore (1976) outlined four 'phases' of public attitudes towards the boomtown experience. These are enthusiasm, uncertainty, near panic and adaptation (p. 536). This, and subsequent boomtown impact models have highlighted the tensions 'oldtimers' (existing residents) and 'new-comers' (new workers) experience. Populations swell with new workers seeking opportunities while at the same time there are increasing demands on local infrastructure health, education, social services and housing. This creates what is often referred to as a 'boomtown syndrome' (Gilmore, 1976). Research into boomtowns (most commonly small towns of a few thousand) has found that while there are both positive and negative economic impacts, the social impacts are predominately negative and a lack of housing can be a 'critical problem' (Jacquet, 2009, p. 17). In the following sections we consider international and Australian research about boomtowns and housing, before thinking through the implications for the city of Darwin.

\section{International research about boomtown housing-related impacts}

There is a growing body of literature concerning the social impacts of natural resource related booming (and 'busting') coming from a range of locations across the globe, (eg Reeves, 2011; Walsh, 2012; Zeller, 2009; Zhang, 2009). However, we have limited our review to Western boomtowns because of similarities in governance and economic structures to Australia, where Darwin is located. The majority of social impacts boomtown research has been in the form of case studies about small sized towns (often less than 15,000 people), and the most of the research (beginning in the early 1970's) was undertaken in the United States and Canada. Most social impacts research considers a range of areas including crime, health, education, social connectedness and community cohesion. Housing is often articulated as one area of social impact, but rarely is it the focus of a study about boomtown impacts.

In early research the 'social disruption' theoretical frame was used to view the changes brought about by booming (England \& Albrecht, 1984). From this perspective, the social impacts of booming were considered predominantly negative and included the breakdown of family and community life, increasing crime, depression and ill-health. The associated 'bust' or downturn after the boom sometimes resulted in rapid population decrease, abandoned towns and livelihoods. The social disruption concept was 
perhaps most famously captured in Kohrs' (1974) study of Gillette, Wyoming. In this study, a picture of family and social disintegration associated with life in sub-standard mobile homes is vividly painted, highlighting the negative consequences of rapid growth for both long term residents and new arrivals.

Two years later, Gilmore's (1976) portrait of the imaginary town of 'Pistol Shot' solidified the negative views of booming. Gilmore (1976, p, 536) outlined the four phases involved in booming: initial enthusiasm and excitement about an increasing population and a larger economy, followed by uncertainty about how to proceed as the size of the boom becomes clearer, then 'near panic' sets in as the reality of overstretched local services, housing stock and other resources is felt, and finally a 'problem solving' phase is reached where solutions to the multiple issues faced by the town are sought.

The social disruption model was critiqued over the following decades by researchers who argued that it was based on flawed methodologies and focused on negative outcomes (Krannich \& Greider, 1984; Wilkinson, Thompson, Renyolds Jr, \& Ostresh, 1982). Smith, Krannich and Hunter (2001) argued that while disruptions do occur, they tend to 'dissipate in the years after the boom' (p. 446). Smith et al (2001, p. 432) provided the following summary of their views about social consequences in general:

On balance, the literature addressing the social consequences of boom growth seems to suggest that disruptive consequences occur under some circumstances... in some places, during some periods of the growth process, and for some segments of the local population.

Yet when 'disruptions' do occur they can include increases in crime (particularly violent crime) (Ruddell, 2011) and fear of crime (Hunter, Krannich \& Smith, 2002); increases in numbers of 'alienated' youth (Freudenberg, 1984) and social isolation (Greider et al 1991); increases in substance abuse and social fragmentation (Parkins \& Angell, 2011): and decreases in community satisfaction with local services and facilities (England \& Albrecht, 1984).

Despite different outcomes in different situations, Jacquet (2009, p. 17) points to the issue of housing as a 'critical problem' in boomtowns, as 'existing housing fills up quickly and new housing takes years to materialize'. He suggests that while 'skyrocketing' housing prices can be beneficial to existing house owners because of the increased value of their asset, increased housing prices can provide a hardship for existing residents who are either not homeowners or plan to remain owner-occupiers of their property'. Extreme housing shortages push the price of housing out of the reach of most workers (even those who have moved for the resource industry jobs) as builders focus primarily on the more lucrative high end of the housing market (Jacquet, 2009, p. 17).

Fort McMurray in Alberta, Canada is similar in size to Darwin, with approx. 85,00o residents (Sheilds, 2012) and is remote, being in northern Canada. Fort McMurray has experienced rapid resource related growth in its economy and population over the past decades which has resulted in a severe housing shortage and extremely high housing costs. Many residents 'were unable to afford housing, even while working full-time', homelessness and 'near homelessness' increased by $24 \%$ in a two year period between 2004 and 2006 (Echenberg \& Jensen, 2009 p. 5). While there are housing developments planned for Fort McMurray, the 'lag' between population increase and suitable accommodation has led to the overcrowding ('basement dwellers'), homelessness and relocation to other cities (Echenberg \& Jensen, 2009 ; Sheilds, 2012).

Research findings show that long term, comprehensive planning and community involvement can prevent some of the more negative aspects of booming. In a social impacts comparative case study involving Canadian Northwest Territories, and Alaskan (USA) sites, Asselin and Parkins (2009) found that extensive consultation, planning and review processes meant that local communities could have input into the resource development processes. This was viewed as positive, and resulted in 'major differences in socio-economic outcomes' when compared to locations that developed rapidly with little planning or community input (Asselin \& Parkins, 2009 p.494).

Other international research points to the idea that locations which have diverse local economies and a relatively small non-resident workforce compared to the resident workforce, experience fewer negative impacts of booming (Jacquet, 2009; Smith et al., 2001). This idea has also recently been articulated in Australian research about boomtowns (Carrington \& Pereira, 2011; Haslam McKenzie, Phillips, Rowley, Brereton, \& Birdsall-Jones, 2009b) and is considered further in the following sections.

\section{Australian research about boomtown housing-related impacts}

As noted by Carrington and Pereira (2011, p. 2), the social impacts of major resource developments on Australian communities are only beginning to receive research attention. Investigations into the impacts of booming upon housing have predominantly focused on small rural and regional towns in Queensland and Western Australia (Carrington \& Pereira, 2011; Haslam McKenzie et al., 2009a, 2009b; Lawrie, Tonts, 
\& Plummer, 2011; Rolfe, Miles, Lockie, \& Ivanova, 2007). Research in these locations has found significant negative impacts on housing affordability and availability. For example, Carrington \& Pereira (2011) investigated the social impacts of resource development on rural towns in Queensland experiencing booms and found that the impact on housing affordability and availability was one of the most pressing issues for residents. One participant's comment summarised the general feeling: 'Permanent residents cop all the negative effects of mining, such as dust and the associated medical issues, noise, increased prices, housing affordability and limited choices of housing options' (Carrington \& Pereira, 2011, p.13).

Other research has highlighted the relationship between housing, the labour market and the overall economy of boomtowns. As Rolfe et, al. (2007, p.145) point out, high housing costs make it 'uneconomic' for people in low paid employment (traditionally service industries and community services) to remain in boomtowns.

Where increased pressure on housing stock drives up housing and rental prices it may become more difficult for people on lower incomes to find affordable housing, reducing further the pool of affordable labour available to other industries. The end result is that uneven growth patterns may generate net economic impacts that are lower than the initial stimulus provided by the key growth industry (Rolfe et al., 2007, p.135).

All the research shows that the most vulnerable members of the population experience the most negative impacts. Haslam-McKenzie et. al. (2009b) undertook research involving four resource-town case study sites, Karratha and Kalgoorlie-Boulder (in Western Australia); and Emerald and Moranbah (in Queensland). They found that the impact of low housing affordability and availability has been particularly hard on the local Indigenous populations, resulting in increased homelessness, overcrowding and relocation to other areas.

In recent years Perth has received much attention as a resource industry fuelled boomtown. While the city itself is not the source of the boom, as the resources are located in remote parts of Western Australia, it is the home of many workers and investors benefitting from the industries in these places. As such, Perth has experienced many boomtown symptoms, with housing stress being one of the worst (Fogarty, 2012; Williams, 2012).

In early 2012 there were media reports concerning the social impacts of the resources boom on Perth, the capital city of Western Australia (Fogarty, 2012; Williams, 2012). Quoting an Anglicare WA report, it was suggested that the biggest impact was housing stress. Reports cited interviews with non-government housing service providers who noted increases in 'the working poor' and a greater demand on their services were all a result of rising house prices due to the resources boom in other parts of the state (Fogarty, 2012; Williams, 2012). Interestingly, Perth's 'boom' is more an economic boom, rather than a population increase boom. While it provides some warnings for Darwin in terms of vulnerable populations, the potential boomtown experience in Darwin is likely to impact in different ways because of the composition of the population as well as economic changes.

Jacquet (2009, p. 52) argued that a community's ability to 'absorb a population influx relative to the community's base population', was a key consideration in understanding potential social impacts of booming. Larger populations are better able to absorb large worker influxes, and impacts on communities and governments are therefore smaller. Because, as mentioned above, most research in Australia has been conducted in places with relatively small populations, it has not been possible to explore these different dependencies, and the extent to which they might mitigate negative impacts. Darwin provides an interesting case to explore, as it is larger than the typical remote Australian boomtown, but much smaller than the other capital cities whose economies (but not necessarily populations) have boomed.

\section{Darwin as a boomtown}

Darwin is the capital city of Australia's Northern Territory located at the remote, tropical 'top end' of Australia (see figure 1). It is a 'newer' capital city, colonised by European settlers much later than the southern parts of the country. In 2011 Darwin had a population of 127,532 people (Australian Bureau of Statistics, 2011). With $20 \%$ of the population born overseas, and $11 \%$ of the people identifying as Indigenous, Darwin is an ethnically diverse city. Unemployment is low (less than $2 \%$ ) for the general population; however it is high for Indigenous Australians (54\%) (Department of Education and Workplace Relations, 2010; Australian Bureau of Statistics, 2011).

The city is experiencing the early stages of booming due in large part to a major offshore gas project. The Inpex Corporation has recently begun construction of a liquefied natural gas (LNG) processing plant near Darwin with workers' villages planned for nearby Howard Springs (see figure 2). The project is valued at approximately \$34 billion (Australian) and will employ approximately 3,00o people during the construction phase, expected to last from the present time until 2016 (Winter \& Taylor, 2012, p. 3). 
We emphasise the 'approximate' nature of these figures as the estimated numbers of workers requiring single person's housing over the coming four years has ranged from 2,700 to 3,500 depending on the source (Icthys Project, 2013; Inpex, 2013; Northern Territory Government, 2011). The approximate figure of 3,000 does not include the employees likely to be required by a range of smaller companies undertaking much of the sub-contracting work. All of these people will require housing of some kind. FIFO workers will need regular, intermittent, short-term accommodation during their 'fly in' working time. Other workers will choose to live in Darwin, some with their families. These people are likely to rent or buy on the open market.

While the ratio between new workers and the current population may end up being small, impacts upon real estate affordability are already being felt. Government and real estate industry fuelled media 'hype' about expected economic prosperity associated with new resource developments is attracting property investors and pushing up prices (Adlam, 2012b; Australian Property Investor, 2012; May, 2012; Rothwell, 2012).

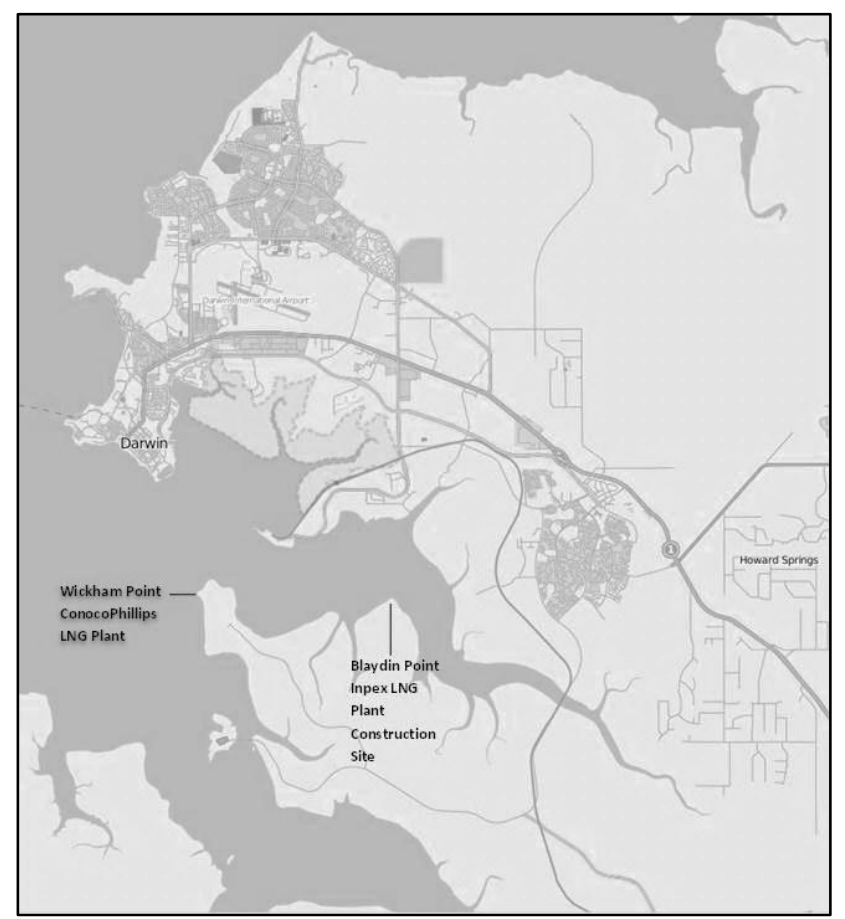

Figure 2. Greater Darwin area with LNG plant sites

\section{Housing is already a major issue for Darwin}

Locating affordable accommodation has long been a challenge in Darwin, but in recent years it has become extremely difficult. While the cost of purchasing housing in Darwin has historically been high compared to most other cities in Australia (attributed to local building costs, lack of labour, building pressures and land release issues), buying a house is now out of reach for an average income earner. Figure 3 demonstrates the rising median costs of houses ( 3 bedroom) and units in Darwin. The final approval decision on the Inpex LNG project was announced in January 2012 and as figure 3 demonstrates, house prices rose steeply from that point. At the end of 2012, median three bedroom house prices in the Darwin region were $\$ 660$,ooo, making it the second most expensive capital city in Australia. The median house price for all capital cities in Australia is currently \$533,00o (Australian Property Monitors, 2012).

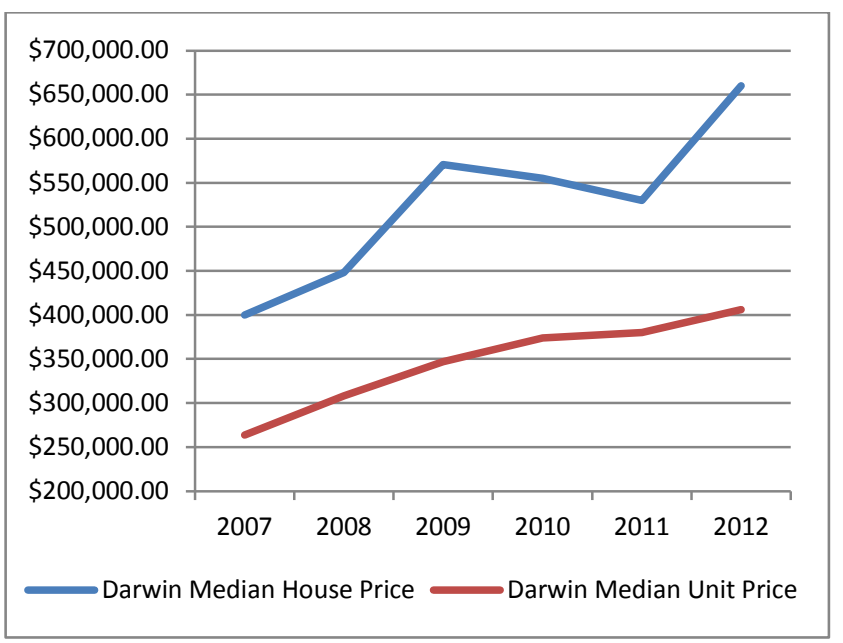

Figure 3. Darwin Median House and Unit Prices 2007 to 2012 (data sourced from NT Shelter, 2012)

The median unit price in the Darwin region is slightly more accessible at $\$ 406$, ooo in line with the national median for unit prices at $\$ 406,000$ (Australian Property Monitors, 2012a).

Darwin is currently the most expensive capital city to rent either houses or apartments. The median rent in Darwin for a house is currently $\$ 700$ per week. This is $\$ 180$ per week more than the next most expensive capital city, Sydney, at $\$ 520$ per week. The median asking rent for apartments in Darwin is currently $\$ 530$ per week, \$60 more expensive than the next most expensive capital city, Sydney, at $\$ 470$ per week (Australian Property Monitors, 2012b).

These year on year increases in rent are staggering. Median rental prices for houses have increased $27.3 \%$ in 12 months, and median rents for units have increased $15.2 \%$ in 12 months (Australian Property Monitors, 2012b). In September 2012 the rental vacancy rate in Darwin was $0.6 \%$, the lowest of all capital cities in Australia (Department of Infrastructure and Transport, 2012). This sort of price increase and lack of availability is consistent with a boomtown scenario experienced in other, much smaller remote locations impacted by resource 
developments (Haslam McKenzie, Phillips, Rowley, Brereton, \& Birdsall-Jones, 2009a).

It can be argued that in previous years, higher incomes of people in the Greater Darwin area have mitigated the high cost of housing to some extent. For example, in 2011, median weekly incomes were much higher in Darwin than in the rest of Australia, with the median household income being 32\% higher than the rest of the country (see table 1). Median weekly rental payments and monthly mortgage repayments data collected in the same 2011 census demonstrate it was $\mathbf{2 1} \%$ more expensive to rent in Darwin that the rest of Australia, and $17 \%$ more was spent on mortgage repayments (as demonstrated in table 2).

From the data in tables 1 and 2 it could be assumed that higher wages make the stress of higher housing costs less acute. However there are two important considerations. Darwin is the most expensive of all Australian capital cities for 'food, alcohol, tobacco, communications and financial and insurance services' (Department of Infrastructure and Transport, 2012, p. 2). Secondly, the data in tables 1 and 2 were collected prior to the rapid increase in housing prices and rents at the start of 2012 (see figure 3). Since then housing costs have increased rapidly but incomes have not.

Table 1. Median weekly incomes Darwin and Australia

\begin{tabular}{|l|c|c|c|}
\hline $\begin{array}{l}\text { Median weekly } \\
\text { incomes }\end{array}$ & $\begin{array}{c}\text { Greater } \\
\text { Darwin }\end{array}$ & Australia & $\begin{array}{c}\% \\
\text { difference }\end{array}$ \\
\hline personal & $\$ 897$ & $\$ 577$ & $36 \%$ \\
\hline family & $\$ 2040$ & $\$ 1481$ & $27 \%$ \\
\hline household & $\$ 1806$ & $\$ 1234$ & $32 \%$ \\
\hline
\end{tabular}

Table 2. Median mortgage and rental payments Darwin and Australia

\begin{tabular}{|l|c|c|c|}
\hline $\begin{array}{l}\text { Mortgage and } \\
\text { rental } \\
\text { payments }\end{array}$ & $\begin{array}{c}\text { Greater } \\
\text { Darwin }\end{array}$ & Australia & $\begin{array}{c}\% \\
\text { difference }\end{array}$ \\
\hline $\begin{array}{l}\text { Median } \\
\text { monthly } \\
\text { mortgage } \\
\text { repayments }\end{array}$ & 2167 & 1800 & $17 \%$ \\
\hline $\begin{array}{l}\text { Median } \\
\text { weekly rent }\end{array}$ & 360 & 285 & $21 \%$ \\
\hline
\end{tabular}

\section{Housing is a particular concern for vulnerable populations}

While the rise in rental prices is appreciated by investors it is a very different story for renters, particularly those on low incomes and/or in receipt of government welfare payments. In their 'Rental Affordability Snapshot 2012', Anglicare Australia found that of 497 rental properties advertised in Darwin, none were suitable (i.e., 'affordable and appropriate') 'for people on Youth and New Start Allowances, Parenting Payment and Disability Support Pensions, and only 20 were suitable for people on some benefits and minimum wages' (Anglicare Australia, 2012, p. 35).

Housing stress is known to have negative impacts on health and wellbeing. As people are forced to pay more for rent and housing expenses, they are less likely to spend their limited dollars on healthcare treatment and health related expenses (Bramley, 2012; Pollack, Griffin, \& Lynch, 2010). In addition as housing becomes more unaffordable, residents may be forced into substandard housing which can further put their health and welfare at risk. Substandard housing and associated health problems are especially a problem for Indigenous residents (Lea, 2008; Lea \& Pholeros, 2010).

Public housing development in Darwin is not keeping up with the demand, nor is public housing being built at a rate quicker than it is being lost. Between 2000 and 2011, the Darwin area lost 27\% of public housing stock (838 dwellings) through sales and a Northern Territory Government policy of nonreplacement (NT Shelter, 2012). Over the same period, the waiting list for public housing in Darwin grew by $151 \%$ to 1,319 people. Waiting list times average between five and six and a half years depending on the type of housing required (NT Shelter, 2012).

Northern Territory media and government reports over recent years have highlighted some of the issues being faced by Darwin's most vulnerable groups in relation to housing. Indigenous people, single parents (predominantly women), parents with disabled children, refugees, young people and people experiencing mental and physical illness, are at extreme risk of being pushed from the private rental market and becoming homeless (Hainke, 2009; Northern Territory Government, 2011; Santow, 2010). Australian literature tells us that homelessness, overcrowded housing, and forced re-location are the major housing-related impacts of boomtowns experienced by low and moderate income households in other resource-dominated locations (Haslam McKenzie et al., 2009a). In particular, it is Indigenous people, women and young adult children who are known to relocate during housing shortages and periods of high rents (Haslam McKenzie et al., 2009a).

In this housing stressed environment, land use issues can become highly charged. In the Darwin region there are a number of Indigenous 
communities (sometimes known as 'town camps') that operate under a range of different governance structures and have varying degrees of tenure over the land they are situated on. Increasingly there are calls by Northern Territory politicians to review and dramatically change some of the Indigenous Communities by opening up the land and homes for sale on the open market (Bardon, 2012; Henderson \& O'Brien, 2011). Currently these communities have different forms of tenure and ownership. If such ideas were to be developed, the repercussion for the Indigenous people currently living in these communities, and those who use them as a base when they travel into town from remote areas, would be immense. With private rentals so difficult to access, Indigenous people dependent upon housing in city-based Indigenous communities could effectively be pushed out of the Greater Darwin area.

Currently the Greater Darwin area is not only experiencing housing stress, but also a shortage of support services for people experiencing the impact of this stress. The number of homeless people in Darwin is estimated to be 2,478 . This equates to a rate of 234 homeless per 10,000 of the population whereas the national average homeless rate is 53 per 10, oooo (Northern Territory Government, 2011). Of note $30 \%$ of the homeless in Darwin are Indigenous. In terms of support for this population in Greater Darwin, there are 1,545 beds available from 101 government funded housing support services. These can be broken down into the following categories:

- $\quad 385$ beds for the general population;

- 554 beds specifically for Indigenous people;

- 141 beds specifically for women;

- 82 beds specifically for men;

- $\quad 248$ beds specifically for families;

- 135 beds specifically for young people. (Northern Territory Government, 2011, p. 11)

It is clear there already exists a major issue with homelessness in Darwin as there are not enough housing or support service beds available to meet current housing needs.

\section{Relating the boomtown literature to the Darwin housing context}

Applying findings from the existing literature about housing-related impacts of boomtown to the Darwin context can be difficult. One of the major differences between Darwin and locations in the literature, is that Darwin existed as a (small) capital city prior to becoming a boomtown. In this respect the city is not dependent upon resource development as the single economic driver. Darwin has a large defence force population, large public sector, and tourism and service industries. According to the literature (Jacquet, 2009; Smith et al., 2001) this diversity of economy should prevent some of the negative extremes of boomtown scenarios, particularly the 'bust' phases.

A bust phase can occur when resource developments are concluded downsized, or commodity prices fall. Boomtown populations often rapidly decrease, leaving a much smaller population than the town originally had. Initial over-building of houses for an expected population growth can have detrimental effects once populations decrease after the initial booming phase. This can leave people with de-valued property and an oversupply of rental housing (Forsyth, Luthra, \& Bankston, 2007; Haslam McKenzie, Brereton, Birdsall-Jones, Phillips, \& Rowley, 2008; Jacquet, 2009; Tonts, Plummer, \& Lawrie, 2012).

Because Darwin's diverse economic base may protect it somewhat from this 'bust' scenario, it arguably serves to make the city a good choice for property investors. This investor appeal means housing rental and purchase prices are likely to continue to rise over the coming years. As previously discussed, Darwin is already experiencing a housing crisis and currently needs more housing options for its relatively large population and diverse economic base. Investors can take advantage of the boom and demand high rents, while knowing that when the spike in resource development subsides, they will experience a soft version of a 'bust'.

As clearly stated by Asselin and Parkins (2009, p. 494), 'negative impacts can be lessened by long term planning, preparation and community support'. While there has been an effort in terms of keeping the Darwin community informed about oil and gas developments, the NT Government and the companies involved have not entered into any long term planning for housing other than the establishment of a workers' village to accommodate the extra short term workers needed for the new LNG plant. Clear population forecasts for Darwin in relation to the expected boom have not been made publicly available. This lack of forecast figures is problematic in terms of the Darwin community's ability to plan for rapid expected changes.

Rolfe et al (2007, p 145) found that workers' villages and camps may well house people employed directly by the resource company (typically fly in, fly out workers on shifts), but a significant amount of the major development project work is typically subcontracted out to other companies. Typically, resource companies do not provide accommodation for these sub-contractors and the sub-contractors' employees and their families, and this results in demands on the local housing market. Research from elsewhere has demonstrated a range of 
problems associated with workers' camps and other temporary housing for resource projects. Many have found that workers' camps and similar large scale temporary accommodation tend to 'degrade the quality of life for inhabitants and the community as a whole' (Massey and Lewis 1979, in Jacquet 2009, p.17). Already there are protest placards and banners in the area directly adjoining the construction site for the workers' village in Howard Springs.

An important consideration for Darwin is the link between housing, the labour market and the 'liveability' of the city. As previously discussed, the most vulnerable members of the Darwin population have already been experiencing housing affordability and availability stress for some time. However, this group is likely to grow in size to include middle income earners not traditionally impacted by housing stress in such a dramatic way. This is likely to have a flow-on impact in terms of workforce shortages. While the oil and gas industry may be creating employment opportunities for some, workers in other lower paid sectors will find it increasingly difficult to remain living in Darwin.

Carson et. al. (2010) suggest that the housing needs of newcomers moving to Darwin for shortterm work in construction and resource sectors differ from those of long-term residents. Newcomers tend to have 'low price and design sensitivity' meaning they are able to afford higher rents than long-term residents employed in other industries, and prefer to live in the inner city (Carson et al., 2010, p. 296). Drawing on ideas from Vaughan (2007), Carson et. al explain that this situation 'displaces existing and long-term residents (particularly those with high price-sensitivity) to outer suburbs which are less well serviced and become the sites of social dysfunction' (Carson et al., 2010, p. 296) .

Media reports highlight that expensive rents in Darwin have been impacting on businesses attempting to attract and retain staff for entry level positions for many years. In 2008 high rental costs were said to be affecting young workers in Darwin, who have been reported as leaving the area for this reason (Bevege, 2008). In 2012 the situation worsened to include shortages of qualified and experienced workers. This situation has been directly attributed to high housing costs (Rawlinson, 2012).

When a city experiences workforce shortages in the service and hospitality, community, welfare and arts sectors (traditionally the lowest paid sectors) it becomes less attractive to permanent residents and those considering long-term relocation. This can result in a post boom net population loss, as those who could not afford to stay have left, and those who came for the boom leave because the city is not attractive in terms of lack of services. For a city which has long sought population growth, an inadequate supply of affordable housing during a boom period means an opportunity lost.

\section{Conclusion}

The current major resource developments in Darwin are being introduced at a time of high house prices, high rents and high rates of homelessness. Existing literature related to housing-related impacts of boomtowns shows increasing homelessness, overcrowding, and relocation are the most likely negative impacts for Darwin. These impacts will more likely be experienced by the most vulnerable members of the population. Traditionally the most vulnerable are those experiencing unemployment or living on low incomes. Arguably this group will grow to include people on middle incomes, who are simply unable to afford to rent as housing costs escalate in Darwin.

The literature indicates that Darwin's diverse economy and relatively large population may insulate the community from some of the typical impacts described in the bust scenarios, for example plunging house prices, high property vacancy rates and high unemployment. However poor planning, and a lack of clarity about the expected population increases, has resulted in insufficient housing to meet the current housing needs, and no planning to meet the increasing needs due to the resource booming and other proposed developments. Conversely this current and projected shortage of housing has made the Greater Darwin area highly appealing to property investors, and this has resulted in rapid price increases since the announcement of the Inpex project.

Decreasing public housing stock and extremely low rental vacancy rates mean an increasing number of people in Darwin will be at risk of overcrowding and homelessness, and this will inevitably impact not only the community as a whole but also on these individuals' health and wellbeing. It is likely that many on low and middle incomes will leave Darwin in favour of locations with a cheaper cost of living. This will have labour market repercussions as traditionally lower paying sectors, such as the community, human services and hospitality industries (all needed to make a city 'liveable') struggle to find employees.

This review of boomtown literature in a Western context has shown that understandings about housing impacts in boomtowns the size of Darwin are limited. The majority of studies have focussed on small, single industry, resource-dependent remote towns. Darwin is a capital city, with a range of industries and a current population large enough to 
ensure that it will still exist as a city long after the current resource related boom. However with thousands of new workers, and in some cases their families, arriving to take advantage of the new employment opportunities, there will inevitably be an impact on housing. This impact is likely to be negative for many, including the most vulnerable, and it will require on-going research to determine the outcomes and to provide an evidence base for future policy making.

Planners and developers need to urgently address the housing crisis in Darwin if after the boom period they want Darwin to return to a stable and varied population with an adequate workforce to service the city.

\section{References}

Adlam, N 2012a,'House stress hits home', NT News, viewed on May $30^{\text {th }}$, www.ntnews.com.au.

Adlam, N 2012b, 'Ichthys could overheat housing, NT News, viewed on 17th March, http://www.ntnews.com.au.

Anglicare Australia 2012, Anglicare Australia Rental Affordability Snapshot, Canberra.

Asselin, J \& Parkins, J 2009,'Comparative case study as social impact assessment: Possibilities and limitations for anticipating social change in the Far North', Social Indicators Research, vol. 94, pp 483-497, doi: 10.1007/s11205-009-944407.

Australian Bureau of Statistics 2011, National Regional Profile: Darwin (Statistical Division), Canberra.

Australian Property Investor 2012, Inpex approval puts gas back into Darwin's property market, viewed on 24 October, http://202.174.100.149/apionline/news/2012/o1/inpex-approval-puts-gas-back-intodarwins-property-market.

Australian Property Monitors 2012a, House Price Report: September 2012, http://www.domain.com.au/content/files/apm/reports/A PM-HousePriceReport-Sep12-FINAL.pdf.

Australian Property Monitors 2012b, Rental Report: September 2012, http://www.domain.com.au/content/files/apm/reports/A PM-Rental-Report-Sept-12-FINAL.pdf.

Bardon, J 2012, Bagot plan upsets indigenous community, http://www.abc.net.au/news/2012-o8-02/bagot-planupsets-indigenous-community/4173544.

Betts, A 2010,'Home wreckers', NT News, viewed on 15th February 2010, http://www.ntnews.com.au.

Betts, A 2012,' Rental subsidy to fight exodus of skills', NT News, viewed on 8 August, http://www.ntnews.com.au.

Bevege, A 2008,'Workers leave NT as housing crisis bites', NT News, viewed on 1st August, http://www.ntnews.com.au

Bramley, G 2012,'Affordability, poverty and housing need: triangulating measures and standards', Journal of Housing and the Built Environment, vol. 27(2), pp 133-151. doi: 10.1007/s10901-011-9255-4.

Calacouras, N 2010a,'Dream's over for tenants', NT News. viewed on 23rd April, http://www.ntnews.com.au.
Calacouras, N 2010b, Many public tenants earning too much', NT News, viewed on 16th May, http://www.ntnews.com.au

Carrington, K \& Pereira, M 2011,'Assessing the social impacts of the resources boom on rural communities', Rural Society, vol. 21(1), pp 2-20.

Carson, D, Schmallegger, D, \& Harwood, S 2010,'A city for the temporary? Political economy and urban planning in Darwin, Australia', Urban Policy and Research, vol. 28(3), pp 293-310.

Department of Infrastructure and Transport 2012, State of Australian Cities 2012, Australian Government, Canberra.

Department of Education and Workplace Relations 2010, Darwin Area Profile, viewed on 24th October, http://www.deewr.gov.au/lmip/default.aspx?LMIP/Emplo ymentData/NorthernTerritory/Darwin.

Echenberg, $\mathrm{H}$ \& Jensen $\mathrm{H}$ 2009, Risk factors for homelessness, Social Affairs Division, Parliamentary Information and Research Service, Ottawa.

England, LJ \& Albrecht, SL 1984,'Boomtowns and social disruption', Rural Sociology, vol. 49(2).

Fogarty, P 2012,'Goodtime for all in boomtown Perth?, News Asia, viewed on October 1, www.bbc.co.uk/news/world-asia-19222037.

Forsyth, CJ, Luthra, AD \& Bankston, WB 2007,'Framing perceptions of oil development and social disruption', The Social Science Journal, vol. 44, pp 287-299.

Freudenburg, WR 1984,'Differential impacts of rapid community growth', American Sociological Review, vol. 49, pp 697-715.

Gilmore, JS 1976,'Boom towns may hinder energy resource development', Science, vol. 191(4227), pp 535-540.

Grieder, T, Krannich, RS \& Berry, EH 1991,'Local identity, solidarity and trust in changing rural communities, Sociological Focus, vol. 24, pp 263-282.

Hainke, N 2009, Refugees caught up in housing shortage', NT News, viewed on and April, http://www.ntnews.com.au.

Haslam McKenzie, F, Brereton, D, Birdsall-Jones, C, Phillips, R \& Rowley, S 2008, A review of the contextual issues regarding housing market dynamics in resource boom towns, Australian Housing and Urban Research Institute, Melborne.

Haslam McKenzie, F, Phillips, R, Rowley, S, Brereton, D \& Birdsall-Jones, C 2009a,'Housing affordability and shortages in resource boom towns', AHURI Research $\mathcal{E}$ Policy Bulletin(120).

Haslam McKenzie, F, Phillips, R, Rowley, S, Brereton, D \& Birdsall-Jones, C 2009b, Housing market dynamics in resource boom towns, Australian Housing and Urban Research Institute, Western Australia Research Centre, Melbourne.

Henderson, A \& O'Brien, K 2011, Tollner leads renewed call to make Bagot a suburb, http://www.abc.net.au/news/2011-10-27/20111027-bagotsuburb-call-tollner/3603834.

Hunter, LM, Krannich, R \& Smith, MD 2002,'Rural migration, rapid growth, and fear of crime', Rural Sociology, vol. 67(1), pp 71-89.

Icthys Project 2013, Icthys Project Community Noticeboard: Accommodation Village, viewed on April $1^{\text {st }}$, http://www.ichthysproject.com/accommodation-village. 
Inpex 2013,'Howard Springs Accommodation Village Update', Icthys Project Fact Sheet, viewed on April $1^{\text {st }}$, http://www.ichthysproject.com/accommodation-village.

Jacquet, J 2009, Energy Boomtowns \& Natural Gas: Implications for Marcellus Shale Local Governments $\mathcal{E}$ Rural Communities, The Northeast Regional Center for Rural Development, Pennsylvania State University.

Kohrs, EV 1974, Social Consequences of Boom Growth in Wyoming, paper presented at the Rocky Mountain American Association of the Advancement of Science Meeting, Laramie, Wyoming, http://www.sublettese.org/files/Social_Consequences_of_Boom_Growth_In_ Wyoming_-_Kohrs.pdf.

Krannich, RS \& Greider, T 1984,'Personal Well-Being in Rapid-Growth and Stable Communities: Multiple indicators and contrasting results', Rural Sociology, vol. 49,pp 451-552.

Lea, T 2008,'Housing for health in indigenous Australia: Driving change when research and policy are part of the problem', Human Organization, vol. 67(1), pp 77-85.

Lea, T \& Pholeros, P 2010,'This is not a pipe: The treacheries of indigenous housing, Public Culture, vol. 22(1), pp 187209.

Langford, B 2010,'Rent rise could leave mother of 4 homeless', NT News, viewed on 26th February, http://www.ntnews.com.au.

Lawrie, M, Tonts, M \& Plummer, P 2011,'Boomtowns, resource dependence and socio-economic well-being, Australian Geographer, vol. 42(2), pp 139-164.

May, L 2012,'Property prices set to soar out of reach', NT News, viewed on January $14^{\text {th }}$, http://www.ntnews.com.au.

Northern Territory Government 2011, Howard Springs accommodation village site finalised for Ichthys, http://newsroom.nt.gov.au/www.newsroom.nt.gov.au/in dexa525.html?d=5\&fuseaction=viewRelease\&id=9002.

Northern Territory Government 2011,'Northern Territory Homelessness Profile Study, Discussion Paper, Department of Housing, Local Government and Regional Services, Darwin, p. 29.

NT Shelter 2012, Housing Fact Sheet, Northern Territory Shelter, Darwin.

Parkins, JR \& Angell, AC 2011,'Linking social structure, fragmentation, and substance abuse in a resource-based community', Community Work and Family, vol. 14(1), pp 39-55.

Pollack, CE, Griffin BA \& Lynch J 2010,'Housing Affordability and Health Among Homeowners and Renters', American Journal of Preventive Medicine, vol. 39(6), pp 515-521. doi: 10.1016/j.amepre.2010.08.002

Rawlinson, C 2012, Housing affordability may threaten Darwin's economic growth, ABC, Local Radio, Darwin.
Reeves, J 2011,'Resources, Sovereignty, and Governance: Can Mongolia Avoid the 'Resource Curse'?, Asian Journal of Political Science, vol. 19(2), pp 170-185. doi: 10.1080/02185377.2011.600165

Rolfe, J, Miles, B, Lockie, S \& Ivanova, G 2007,'Lessons from the social and economic impacts of the mining boom in the Bowen Basin 2004-2006, Australasian Journal of Regional Studies, vol. 13(2)

Rothwell, N 2012,'City of dreams faces another rude awakening, The Australian, viewed on May $12^{\text {th }}$, http://www.theaustralian.com.au.

Ruddell, R 2011, Boomtown Policing: Responding to the Dark Side of Resource Development', Policing, vol. 5(4), pp 328-342. doi: 10.1093/police/paro34

Santow, S 2010, Affordable housing a problem for refugees, ABC, AM, Radio National, Sydney.

Sheilds, R 2012,'Feral suburbs: Cultural topologies of social reproduction, Fort McMurray, Canada', International Journal of Cultural Studies, vol. 15(3), pp 205-215.

Smith, MD, Krannich, RS \& Hunter, LM 2001,'Growth, decline, stability, and disruption: A longitudinal analysis of social well-being in four western rural communities', Rural Sociology, vol. 66(3), pp 425-450.

Tonts, M, Plummer, P, \& Lawrie, M 2012,'Socio-economic wellbeing in Australian mining towns: A compariatve analysis', Journal of Rural Studies, vol. 28, pp 288-301.

Vaughan, L 2007,'The spatial syntax of urban segregation', Progress in Planning, vol. 67(3), pp 205-294.

Walsh, A 2012,'After the rush: living with uncertainty in a Malagasy mining town. [Essay], Africa, vol. 82(2), pp $235^{+}$.

Wilkinson, KP, Thompson, JG, Renyolds, RR Jr \& Ostresh Ostresh, LM 1982, Local Social Disruption and Western Energy Development: A critical review, Pacific Sociological Review, vol. 25, pp 275-296.

Williams, R 2012,'Resources boom cuts deep in city', The Sydney Morning Herald, viewed on January $7^{\text {th }}$, http://www.smh.com.au.

Winter, J \& Taylor, A 2012, Welcome to the boomtown! Darwin and the 'Boomtown Syndrome', The Northern Instituture, Charles Darwin University, Faculty of Law, Education, Business and Arts, Darwin.

Zeller, W 2009,'Danger and Opportunity in Katima Mulilo: A Namibian Border Boomtown at Transnational Crossroads*, Journal of Southern African Studies, vol. 35(1), pp 133-154. doi: 10.1080/03057070802685619

Zhang, H 2009, 'Labor Migration, Gender, and the Rise of Neo-Local Marriages in the Economic Boomtown of Dongguan, South China', Journal of Contemporary China, vol. 18(61), pp 639-656. doi: 10.1080/1067056090303393. 